\title{
Üstün Yetenekli Çocukların Hakları Anne Baba ve Öğretmenler İçin El Kitabı
}

INCELEYEN: HILLAL KAZICI

\author{
"Bir ülkenin uygarlık düzeyi, o ülkede özel \\ eğitim gereksinimi olan çocuklara sağlanan \\ eğitim ve öğretim olanakları ile ölçülür." \\ Mitat ENÇ
}

Bireylerin korunmasını, çeşitli imkânlara erişmesini ve toplumun refah düzeyini yükseltecek olgunlukta yetişmesini sağlamak amacıyla sunulan hukukî olanaklara hak denir (https://sozluk. adalet.gov.tr/hak). Demokratik toplumlarda dünyaya gelen her birey doğuştan bir takım haklara sahiptir. Bireyin haklarını korumak ve uygulamaya geçirmek esasında devletin görevidir. Devletin bütün bireylerin hakkını kusursuz bir biçimde tek tek takip etme ve uygulama çabası ise birtakım karmaşıklıkları beraberinde getirebilir (Enç, 2005, s. 15-18). Çok sayıda bireye

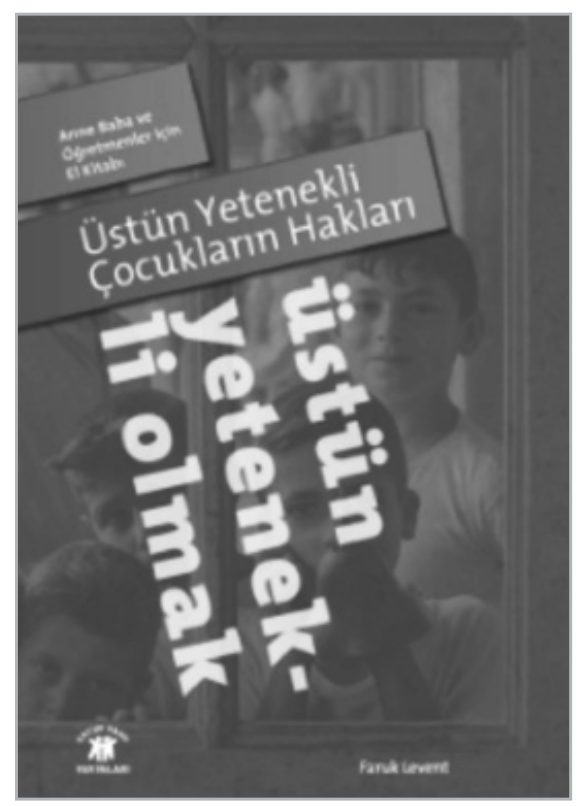
ulaşmak amacıyla toplumda niceliksel bakımdan geniş alanı kaplayan kesimlere ilişkin hakları öncelemek uygulanması kolay bir çözüm yolu olsa da- bazı önemli hakların gözden kaçmasına sebep olabilmektedir. Bu nedenle nicelik açısından toplumda dar

- KITAP INCELEMESI-

HILAL KAZICI, hilalkazici@hotmail.com Rehber Ögretmen ORCID: https://orcid.org/0000-0001-8084-5748

doi: https://doi.org/10.47646/CMD.2020.217 
bir alanı kapsayan ama nitelik açısından toplumda büyük önem arz eden üstün yetenekli çocukların haklarını gün yüzüne çıkartmak elzemdir.

Doç. Dr. A. Faruk Levent'in Üstün Yetenekli Çocukların Hakları adlı çalışması 2011 yılında Çocuk Vakfı Yayınları'ndan çıkmıştır. I. Türkiye Çocuk Hakları Kongresi'nde bildiri olarak sunulan eser altı bölümden oluşmaktadır. Eserde; üstün yetenekli çocukların haklarına dikkat çekilmiş, ülkemizdeki ve yabancı ülkelerdeki mevcut yasal düzenlemeler ortaya konularak, uluslararası sözleşmeler çerçevesinde mercek altına alınmıştır. Faruk Levent eserin amacını şu şekilde ifade etmektedir: " $B u$ çalışmadan beklenen en büyük yarar, üstün yetenekli çocukların hakları konusunda kamuoyunu bilgilendirmek ve yeni yasal düzenlemelerin hazırlanmasına dayanak oluşturmaktadır."(Levent, 2011, s.17). Alt başlıkta "Anne Baba ve Öğretmenler İçin El Kitabı” ifadesinin yer alması çalışmanın geniş bir kesime hitap ettiğini göstermektedir.

Üstün Yetenekli Çocuk ve Eğitimi başlıklı birinci bölümde konuyla ilgili kavramsal bir çerçeve çizilmiştir. İlk olarak mevcut mevzuatlarda yer alan üstün yetenekli çocuk kavramının tanımlarına yer verilmiştir. Genel olarak kabul gören tanımın ABD Milli Eğitim Bakanlığı tarafından 1993 yılında önerilen şu tanım olduğu belirtilmiştir: "Aynı yaş, deneyim ve çevre şartlarına sahip akranlarnna göre, üstün performans gösteren veya yüksek düzeyde başarı elde eden çocuklar ve gençlerdir."(Levent, 2011, s.21). Üstün yetenekli çocukların nitelikleri ele alınırken de yine çeşitli kaynaklardan yararlanılmıştır. Söz konusu nitelikler genel itibariyle şu şekilde özetlenmiştir: Fiziksel enerjileri yüksektir, merak duyguları oldukça güçlüdür, aynı probleme çeşitli çözümler üretebilirler, kelime dağarcıkları geniştir, analitik düşünme yetileri güçlüdür, yaratıcıdırlar, mükemmeliyetçidirler, otokontrol sağlamakta güçlük çekmezler, duygusal bakımdan hassas bir yapıya sahiptirler (Levent, 2011, s.24-25). Yazara göre bu nitelikleri taşıyan çocuklar kendi potansiyellerini geliştirecek yeterliliğe sahip eğitim programlarıyla desteklenmelidir. Bu bağlamda üstün yetenekli çocukların iki önemli ihtiyacı vardır: Doğuştan sahip oldukları yeteneklerinin geliştirilmesi ve zorlayıcı-motive edici etkinlikler. Üstün yetenekli çocukların eğitsel ihtiyaçlarının karşılanmaması onların mevcut yetenek ve potansiyellerini kullanabilmelerinin önünde büyük bir engel oluşturmaktadır. Sözlerine "Böyle bir eksiklik ise bu çocuklara karşı bir anlamda yaptırım uygulamakla eşdeğer olarak görülebilir”(Levent, 2011, s.26) diyerek devam eden yazar; ülkemizde üstün yetenekli bireylerin özel öğrenme gereksinimlerine cevap verecek ve öğrenme hızlarına uygun özel eğitim politikalarının da geliştirilmesi gerektiğinin altını çizmiştir (Levent, 2011, s.27). 
Üstün Yetenekli Çocukların Hakları başlıklı ikinci bölümde üstün yetenekli çocuk hakları iki adımda ele alınmıştır. İlk adımda üstün yetenekli çocuk hakları temel kavramlar açısından değerlendirilmiştir. Bu bölümde üstün yetenekli çocukların daha çok eğitim hakkı üzerine durulmuştur. Toplumun her bireyine kendi yetenekleri ölçüsünde eğitim hakkı verilmesinin gereğini ve temel dayanaklarını açıklayan yazar, üstün yetenekli çocuklar için özel eğitimin doğal bir hak olduğunu ifade etmektedir. Ona göre özel eğitime gereken önemi vermek demokratik bir toplum olmanın gereğidir. Demokratik toplumlarda sık sık dile getirilen "eğitimde fırsat eşitliği" ilkesi de özel eğitimin önemine işaret etmektedir. Bu ilke ile özel eğitim arasındaki bağlantı şu şekilde ifade edilmiştir:

"Eşit fırsata sahip olmak demek, aynı fırsata sahip olmak demek değildir; her bireyin kendi gereksinimlerine uygun deneyimlere sahip olması demektir...Dolayısıyla eşitlik, bireyin doruk noktasına ulaşabilmesi için, onlara eşit fırsatların sunulması anlamına gelmektedir." (Levent, 2011, s.45).

Bu açıklama özel eğitimin haksız bir ayrımcılık olmadığını, aksine âdil bir eğitim sisteminin sağlanması açısından oldukça önemli olduğunu göstermektedir. Üstün yetenekli çocukların haklarını sosyolojik, psikolojik, pedagojik açıdan ele almaya çalışan yazar şu ifadelerle konunun stratejik önemine dikkat çekmiştir: "Bir beşeri kaynak olarak üstün yetenekli potansiyel, bir ülkenin kalkınması, gelişmesi, vizyonu, uluslararası konumu, etkisi ve geleceği için son derece stratejik bir önem arz etmektedir." (Levent, 2011, s.50). İkinci adımında ise üstün yetenekli çocukların hakları uluslararası sözleşmeler açsından değerlendirilmiştir. Bu bağlamda uluslararası öneme sahip üç sözleşme mercek altına alınmıştır: Birleşmiş Milletler İnsan Hakları Beyannamesi, Çocuk Hakları Sözleşmesi ve Herkes İçin Eğitim Beyannamesi. Yazar üstün yetenekli çocukların haklarını doğrudan veya dolaylı olarak konu edinen maddeleri büyük bir titizlikle seçmiş ve objektif bir tavırla analiz etmiştir. Yaptığı analizleri sade bir üslupla aktararak toplumun her kesimine hitap etmeye özen göstermiştir.

Üstün yetenekli çocukların yetişmesinden sorumlu olan ebeveynler çocuklarına ve kendilerine sunulan haklardan bîhaber oldukları sürece yapılan çalışmalar havada kalacaktır. Bu önemli hususa dikkat kesilen yazar, çalışmasının üçüncü bölümünü üstün yetenekli çocuğa sahip ailelerin haklarına ayırmıştır. Üstün yetenekli çocukların hak ettikleri olanaklara erişebilmeleri için ailenin, öğretmenin ve devletin üzerine önemli sorumluluklar düştüğünü vurgulamıştır (Levent, 2011, s.88). Ailelerin ve öğretmenlerin üstün yetenekli çocukların haklarını bilmeleri gerektiğini

Üstün Yetenekli Çocukların Hakları

Anne Baba ve Öğretmenler İçin El Kitabı 
belirtmiş ve onları toplum içinde bir farkındalık oluşturmaya davet etmiştir. Çalışmanın devamında ise söz konusu farkındalığı oluşturmaya yarayacak kaynaklara ulaşma imkânı sunmuştur. Dördüncü bölümde ülkemizde üstün yetenekli çocuklara yönelik uygulamalar ve yasal düzenlemelere yer vermiştir. Sadece kendi ülkemizdeki çalışmaları incelemekle yetinmeyen yazar, başlıca Avrupa Birliği ülkelerinin ve Amerika'nın başlıca eyaletlerinin üstün yetenekli çocuk haklarına ilişkin yasal düzenleme ve uygulamalarına da göz atmıştır. Böylelikle konuyla ilgili çeşitli açılardan karşılaştırma yapmanın yolunu çizmiştir (Levent, 2011, s.73-191).

İsteyen herkesin internet ortamında rahatlıkla ulaşabileceği ${ }^{1}$ bu eser, üstün yetenekli çocukların haklarını gün yüzüne çıkarma çabasının bir ürünüdür. Anne, baba ve öğretmenler için el kitabı olmasının yanı sıra konuyla ilgili detaylı bilgiye ulaşmak isteyenler için de önemli bir veri kaynağı niteliğindedir.

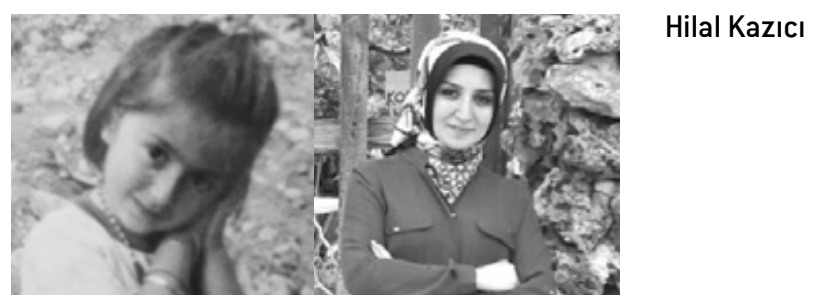

\section{Kaynakça}

Enç, M. (2005). Üstün Beyin Gücü (2. b.). Ankara: Gündüz Eḡitim Yayıncılık. Levent, F. (2011). Üstün Yetenekli Çocukların Hakları El Kitabı. İstanbul: Çocuk Vakfı Yayınları. https://sozluk.adalet.gov.tr/hak (Erișim: 05.12.2020) 